\title{
WYKORZYSTANIE MYŚLENIA I DZIAŁANIA DO STRATEGII PRZEDSIĘBIORCZEJ
}

https://doi.org/10.33141/po.2019.05.02

Mariusz Bratnicki, Paweł Brzeziński
Przegląd Organizacji, Nr 5 (952), 2019, ss. 9-15 www.przegladorganizacji.pl @Towarzystwo Naukowe Organizacji i Kierownictwa (TNOiK)

\section{Wprowadzenie}

C elem niniejszego artykułu jest zaproponowanie zmodyfikowanego współczesnym kontekstem spojrzenia na dialektykę tworzenia strategii $\mathrm{w}$ przedsiębiorczych organizacjach. Współczesne zarządzanie wyróżnia się napięciami, dualnościami, sprzecznościami, dialektyką i paradoksami (Bratnicka-Myśliwiec, 2016, s. 58). Niezbędne jest w tym ujęciu zrozumienie natury kontekstu organizacyjnego znajdującego wyraz w sytuacyjnych ograniczeniach i szansach, które mają zdolność oddziaływania na pojawienie się i znaczenie zachowania organizacyjnego (Johns, 2017, s. 578), a zwłaszcza na zachowanie strategiczne. Stymulatory kontekstualne zarządzania strategicznego - odgórne, oddolne czy też mediujące bardziej odległe efekty - ulegają szybkim przeobrażeniom $\mathrm{w}$ ramach ewolucyjnych sił kształtujących przetrwanie organizacji. Prowadzi to do przewidywanych intuicyjnie skutków działalności menedżerskiej, a w ślad za tym wywraca dominujące dotychczas przeświadczenia o tym, gdzie są źródła skutecznego zarządzania.

Równocześnie w ostatnich dekadach jesteśmy świadkami znacznego wzrostu zainteresowania badaniami przedsiębiorczości, z których wyłania się całościowe spojrzenie na dynamikę kształtowania powiązań pomiędzy kontekstem otoczenia, procesami przedsiębiorczymi oraz interakcjami $\mathrm{w}$ gronie interesariuszy prowadzącymi do tworzenia i zatrzymywania wartości (Agarwal i in., 2017, s. 198). Zarazem przedsiębiorstwa aktualnie funkcjonują $\mathrm{w}$ wysoce konkurencyjnym otoczeniu oraz ulotnych rynkach, gdzie przesunięcia w strategii są krytyczne i konieczne (Garg, Eisenhardt, 2017 , s. 1853). Zatem trudno jest przecenić rolę prawidłowo sformułowanej strategii przedsiębiorczej dla tworzenia i przechwytywania wartości. Strategia przedsiębiorcza jest to długofalowe ukierunkowanie przedsiębiorstwa oparte na rozpoznawaniu szans i mające na celu względnie trwałą przewagę konkurencyjną.

W tym duchu można argumentować, że warto odejść od uniwersalistycznego ujęcia przedsiębiorczej strategii i skupić zainteresowania naukowe na podejściu bardziej kontekstowym: zniuansowanym i dopasowanym do istniejących realiów zarządzania pojawiających się na różnych poziomach analizy. Tym bardziej, iż dotychczasowe teorie i konstrukty tracą swą przydatność (Benner, Tushman, 2015, s. 13). Dlatego też zarówno zwrócenie się ku dostrzeżonej potrzebie uwzględniania kontekstu, jak i narastające zainteresowanie problematyką przedsiębiorczości organizacyjnej nadaje dużą wagę odpowiedzi na postawione $\mathrm{w}$ artykule pytanie badawcze: Jak kształtować przedsiębiorczą strategię organizacji funkcjonującej i rozwijającej się we współczesnym otoczeniu?

Szukając rozwiązania tego problemu, można przyjąć, że nowy kontekst zarządzania zmienia interpretację procesów tworzenia przedsiębiorczej strategii, a w szczególności jest źródłem wyłaniających się tendencji w praktykach menedżerskich oraz leżących u ich podłoża założeń. W tym sensie następują istotne przekształcenia logiki zarządzania, a pośród nich poczesne miejsce zajmuje radzenie sobie $\mathrm{z}$ organizacyjnymi sprzecznościami, napięciami, paradoksami. Potrzeba ta narasta $\mathrm{w}$ organizacjach przedsiębiorczych, gdzie formułowanie strategii jest naprawdę dużym wyzwaniem. Pomimo silnego oddziaływania okoliczności kontekstualnych kadra zarządzająca ma znaczną swobodę wyboru strategicznego, przy czym owa swoboda jest wpleciona $\mathrm{w}$ godzenie sprzeczności pomiędzy działaniem (strategia wyłaniająca się) a myśleniem (poznawaniem dla potrzeb strategii zamierzonej). Dla odpowiedzi na postawione $\mathrm{w}$ artykule pytanie badawcze zastosowano analizę literatury tematu, która z jednej strony pozwala na wyłonienie i przystosowanie postawionego problemu badawczego do wiedzy już istniejącej, a z drugiej strony umożliwia zaproponowanie nowego ujęcia jego rozwiązania.

\section{Podstawy współczesnego myślenia o zarządzaniu}

ak podpowiada M.S. Peck (2003, s. 44), należy poszukać lepszego zrozumienia, ale nie dążyć do większego szczegółu. Wiele osób z powodu swojej pasywności, uzależnienia, strachu czy lenistwa zmierza do określenia każdego centymetra drogi, przy czym dba o to, aby każdy kolejny krok był bezpieczny. Jest to niemożliwe do osiągnięcia. Stąd też można uważać, że rozwój wymaga odwagi, inicjatywy, niezależności myślenia, działania, a przede wszystkim twórczości. Stwierdzenie to jest dobrym punktem wyjścia do identyfikacji podstawowych nurtów współczesnego myślenia o zarządzaniu. W szczególności są to teorie organizacji uwypuklające potrzebę 
radykalnego przeobrażenia zarządzania (Brinkinshaw, 2010), rolę twórczej strategii organizacji (Dyduch, 2013), orientacji pozytywnej (Zbierowski, 2012), szczęśliwości (Judge, Kammeyer-Mueller, 2011), zdrowia organizacyjnego (Bratnicki i in., 2014; Stanford, 2013), pokory (Owens i in., 2013), architektury innowacji (Lerner, 2012), mądrości organizacyjnej (Cowan, Darsoe, 2008), a także fizyki społecznej odzwierciedlającej konwergencję nauk fizycznych i społecznych (Pentland, 2014).

$\mathrm{Na}$ tle zarysowanych koncepcji organizacji można zaprezentować logikę myślenia o wciąż aktualnych problemach nowoczesnego zarządzania, która jest wynikiem ponownej refleksji nad przemyśleniami poczynionymi pięć lat temu (Bratnicki, 2014). Ostateczne wyniki tego odnowienia przedstawiają się jak następuje:

1. Współczesne problemy zarządzania nie mogą być prawidłowo sformułowane, a tym bardziej rozwiązane w kategoriach dotychczas przeważających starych rozwiązań.

2. Jeżeli chcemy rozwiązać problemy zarządzania, to musimy przejść do radykalnie nowych, twórczych sposobów myślenia. Upieranie się przy starych rozwiązaniach prowadzi do menedżerskiej ruiny.

3. Zmiana jest trudna i częstokroć bolesna. Nie ma nadziei na osiągnięcie nowych sposobów myślenia o zarządzaniu bez uczciwej akceptacji bólu i radości związanych $\mathrm{z}$ rozwojem organizacji.

4. Nowe rozwiązania nie dadzą się wyrazić w starym i znanym języku. Dla nowych myśli potrzebny jest nowy słownik - nowy język, nawiązujący do twórczości, przedsiębiorczości, a także innowacyjności.

5. Podstawowym zadaniem kadry zarządzającej jest oderwanie się od szczegółów i zgłębienie istoty problemu. Wyobraźnia jest równie ważna jak wiedza, nie mówiąc już o kluczowej roli twórczości. Charyzma i wizja są niezbędnymi składnikami przywództwa menedżerskiego, ale pierwszoplanową rolę odgrywa zdolność zobaczenia ogólnego obrazu całości.

6. Istotne problemy zarządzania nie dają rozwiązywać się na powierzchni; poprzez likwidację objawów. Konieczne jest myślenie o tych problemach w twórczy sposób polegający na dokładnym określeniu ich źródeł i zrozumieniu przyczyn oraz na poszukiwaniu najlepszego rozwiązania, unikając schematów myślenia i starając się łączyć odmienne punkty widzenia i perspektywy.

7. Nawet najbardziej nieprawdopodobne zdarzenia, o jakich można sobie pomyśleć, mogą stanąć przed nami. Co więcej pomiędzy nimi mogą wystąpić nietypowe, dziwne powiązania, co bez wątpienia wpływa na naszą zdolność do przewidywania tych zdarzeń i nadawania im sensu. Rzeczy wydają się być tak złożone, że działania, które wydają się dobre, mogą prowadzić do efektów zupełnie przeciwstawnych do tego, co zamierzano.

8. Coś, co w izolacji wydaje się być dobre, funkcjonalne, efektywne, może prowadzić do efektów przeciwstawnych intencjom - o ile nie uwzględni się całej złożoności zarządzania strategicznego.
9. Jeżeli przyjmujemy nieprawidłowe założenia, to należy je zmienić oraz wypracować nowe organizacyjne polityki i procedury wychodzące $z$ odmiennego od dotychczasowego zbioru przekonań. W przeciwnym przypadku wciąż będziemy odtwarzali problem zarówno $\mathrm{w}$ rozmaitych formach, jak i w różnych częściach organizacji.

Zatem to, w co wierzymy, że doprowadza do wysokiej efektywności organizacyjnej wymaga zasadniczej transformacji. Niezbędne jest przestawienie menedżerskiego umysłu od perspektywy aktualnie dominującej do pożądanego spojrzenia na zarządzanie organizacją. To nowe podejście do zarządzania opiera się na zmianie podstawowych założeń. Szczegóły wzmiankowanego przejścia zawarto $\mathrm{w}$ tabeli 1 .

Założenia są tak ściśle związane z czynnikami technologicznymi, społecznymi, organizacyjnymi, że trudno jest wprost powiedzieć, gdzie kończą się jedne, a zaczynają drugie. W rzeczywistości stanowią one kompletny kontrakt społeczny dla prowadzenia działalności organizacyjnej. Niepowodzenia w działalności mają swe źródła w niepowodzeniu dostrzeżenia zmian zachodzących w założeniach. Cała trudność tkwi w tym, że zbiór reguł mających sens przez długi czas nabiera charakteru prawd oczywistych. Długotrwały sukces prowadzi do przekonania o znalezieniu magicznej formuły na powodzenie, odpowiedniej na wszelkie czasy. Wszystko to ma kluczowe znaczenie dla kształtowania proefektywnościowej kultury organizacyjnej.

\section{Dylemat swobody manewru strategicznego $\mathrm{w}$ przedsiębiorczych organizacjach}

ednym z głównych wyróżników organizacji przedsiębiorczych jest tworzenie wartości $\mathrm{w}$ warunkach niepewności (Furr i in., 2017, s. 6). Przy takim podejściu do formułowania strategii przedsiębiorczej jako przesłanki rozwoju organizacji trudno uciec od nadawania sensu oraz improwizacji (Bratnicki, 2011) czy też organizacyjnego uczenia się (Bratnicki, 2010). Oto przyczyna, dla której tworzenie przedsiębiorczej strategii przebiega $\mathrm{w}$ przestrzeni menedżerskiej zakreślonej przez działanie - $\mathrm{z}$ jednej strony, a myślenie - $\mathrm{z}$ drugiej (Ott i in., 2017, s. 315). W tym stanie rzeczy uproszczone rozwiązania są niewiele warte. Należy przemieścić punkt skupienia uwagi w procesach tworzenia strategii od specyficznego kontekstu, treści i dynamiki do syntetyzowania strategicznych paradoksów (Bratnicki, 2000, s. 144).

Nie wchodząc we wciąż żywą dyskusję odnośnie do ontologicznych korzeni szans (Alvarez i in., 2017; Ramaglou, Tsang, 2017), można przyjąć rozumienie przedsiębiorczości organizacyjnej jako proces rozpoznawania oraz wykorzystywania szans w celu tworzenia i przechwytywania wartości. Bez wątpienia w rozważaniach o przedsiębiorczej strategii jednym z najważniejszych dylematów jest dylemat swobody manewru konkurencyjnego, którego istota zawiera się w godzeniu 
Tabela 1. Obecnie dominujące i pożądane spojrzenia na zarządzanie organizacją

\begin{tabular}{|c|c|}
\hline Spojrzenia obecnie dominujące & Spojrzenie pożądane \\
\hline $\begin{array}{l}\text { 1. Efektywność organizacji może być osiągnięta bez głęboko } \\
\text { zakorzenionej potrzeby i troski ze strony bezpośrednich } \\
\text { wykonawców i kadry zarządzającej. Na przykład można } \\
\text { osiągnąć wysoką jakość, wprowadzając odgórnie } \\
\text { stosowne reguły i procedury. }\end{array}$ & $\begin{array}{l}\text { 1. Efektywności organizacyjnej nie można osiągnąć bez } \\
\text { głęboko zakorzenionej potrzeby i troski ze strony } \\
\text { każdego uczestnika organizacji. }\end{array}$ \\
\hline $\begin{array}{l}\text { 2. Wysoka efektywność może być osiągnięta jedynie } \\
\text { za pomocą jasno sformułowanych celów, które } \\
\text { pozwalają ustalić ścisłe mierniki kontroli procesów } \\
\text { organizacyjnych. }\end{array}$ & $\begin{array}{l}\text { 2. Efektywność organizacyjna wymaga pracowników, którzy } \\
\text { posiadają trwałą i wyraźną potrzebę jej osiągnięcia oraz } \\
\text { dążą do ciągłej poprawy efektywności nawet wtedy, gdy } \\
\text { brak wyraźnych celów ukierunkowanych na wysoką } \\
\text { efektywność organizacyjną. }\end{array}$ \\
\hline $\begin{array}{l}\text { 3. Warunkiem wystarczającym dla osiągnięcia wysokiej } \\
\text { efektywności jest sformułowanie jednoznacznych celów } \\
\text { i odpowiadających im zadań. }\end{array}$ & $\begin{array}{l}\text { 3. Warunki konieczne do osiągnięcia wysokiej efektywności } \\
\text { to zarówno cele i zadania w postaci spójnego } \\
\text { zbioru polityki strategicznej, jak i postawy szeroko } \\
\text { rozpowszechnionej w organizacji, a także ukryte } \\
\text { pragnienie ze strony każdego pracownika, aby wyjść poza } \\
\text { zapisane polityki organizacyjne. }\end{array}$ \\
\hline $\begin{array}{l}\text { 4. Wysoką efektywność osiąga się, rozważając jedynie } \\
\text { czynniki i uwarunkowania w obrębie organizacji. Źródła } \\
\text { niskiej efektywności organizacyjnej tkwią bezpośrednio } \\
\text { w organizacji. }\end{array}$ & $\begin{array}{l}\text { 4. Wysoką efektywność osiąga się, uwzględniając czynniki } \\
\text { i uwarunkowania zarówno wewnętrzne, jak i zewnętrzne. } \\
\text { Źródła niskiej efektywności tkwią zarówno w organizacji, } \\
\text { jak i poza nią. }\end{array}$ \\
\hline $\begin{array}{l}\text { 5. Bezpośredni wykonawcy są najbardziej oczywistą } \\
\text { przyczyną niskiej efektywności organizacji. }\end{array}$ & $\begin{array}{l}\text { 5. Bezpośredni wykonawcy stają się kozłami ofiarnymi } \\
\text { wtedy, gdy nie dociera się do „prawdziwych” źródeł } \\
\text { niskiej efektywności organizacji. }\end{array}$ \\
\hline $\begin{array}{l}\text { 6. Występuje nikły związek pomiędzy odległymi, mało } \\
\text { prawdopodobnymi zdarzeniami. }\end{array}$ & $\begin{array}{l}\text { 6. Dowolna liczba zdarzeń występująca gdziekolwiek } \\
\text { na globie może obecnie wzajemnie być powiązana na } \\
\text { nietypowe, a nawet dziwne sposoby. }\end{array}$ \\
\hline $\begin{array}{l}\text { 7. Organizacje nie tworzą kryzysów, wobec których stoją. } \\
\text { Kryzysy po prostu zdarzają się. }\end{array}$ & $\begin{array}{l}\text { 7. Organizacje tworzą kryzysy, z którymi mają do czynienia. } \\
\text { Robią to w tym specyficznym sensie, że rodzaje systemów } \\
\text { wczesnego ostrzegania, prewencji, ograniczania szkód, } \\
\text { odkrywania i uczenia się są jednym z najważniejszych } \\
\text { czynników kształtujących charakter rzeczywiście } \\
\text { występujących kryzysów. }\end{array}$ \\
\hline $\begin{array}{l}\text { 8. Organizacja jest w stanie realizować własną drogę } \\
\text { wzrostu niejako poza istotą problemów zarządzania. }\end{array}$ & $\begin{array}{l}\text { 8. Organizacja jest w stanie rozwiązać problemy zarządzania } \\
\text { tylko wtedy, gdy uczy się rozwijać w stosunku do } \\
\text { charakteru tych problemów. }\end{array}$ \\
\hline
\end{tabular}

Źródło: opracowanie własne

formalnego planowania strategicznego ze strategicznym oportunizmem, polegającym na wykorzystywaniu nadarzających się szans. To właśnie strategie ożywiania przedsiębiorczości pozwalają skutecznie zespolić wskazaną sprzeczność strategiczną. Jak przedstawiono w tabeli 2, na krańcu działania występują różne rodzaje organizacyjnego uczenia się.

I tak metoda prób i błędów polega na tym, że kadra zarządzająca zmienia swoje zachowania w odpowiedzi na negatywne rezultaty, a zarazem pozostawia zachowania dające pozytywne skutki. Oznacza to stopniowe tworzenie strategii odpowiednio do konsekwencji podjętych działań. Ważne jest przy tym, aby metoda prób i błędów służyła do budowania prostych regul, które tworzą podstawę strategii. Majsterkowanie (bricolage) odnosi się do robienia czegoś za pomocą kombinacji dostępnych zasobów w celu rozwiązania nowych problemów bądź wykorzystania szans. Inaczej mówiąc, chodzi tutaj o użytkowanie istniejących zasobów w oryginalny sposób po to, aby stworzyć nowe źródła wartości. Omawiany proces ma dwoisty charakter znajdujący wyraz zarówno w kształtowaniu strategii przy wykorzystaniu minimalnych zasobów, jak i tworzeniu strategii wychodzącej poza ograniczenia bieżącej działalności. Kolejna postać uczenia się to improwizacja pozwalająca tworzyć strategię niejako w biegu. Forma ta jest szczególnie korzystna w okolicznościach charakteryzowanych niespodziankami. To właśnie dzięki improwizacji przedsiębiorstwo nabywa elastyczności niezbędnej do wygenerowania nowego ciągu strategicznego. Całość uczenia się z doświadczeń dopełnia eksperymentowanie, które polega na kontroli różnych aktywności wraz z ich kontekstem dla wytworzenia nowej wiedzy i zmniejszenia niepewności. W szczególności eksperymentowanie mające na celu sprawdzenie założeń przyspiesza tworzenie strategii i zwiększa jej efektywność. 


\begin{tabular}{|c|c|c|c|c|c|c|c|}
\hline \multirow{3}{*}{ 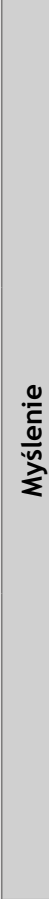 } & 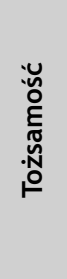 & 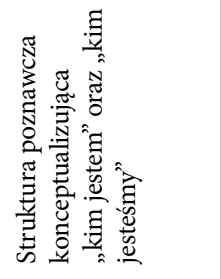 & 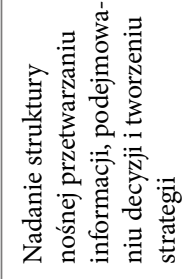 & 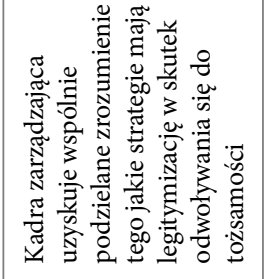 & 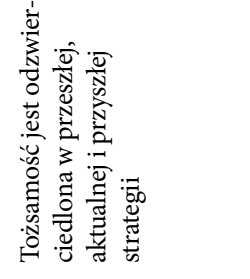 & 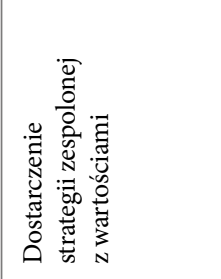 & 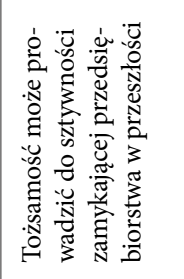 \\
\hline & $\begin{array}{l}\frac{\sigma}{0} \\
\frac{0}{00} \\
\frac{\sigma}{4}\end{array}$ & 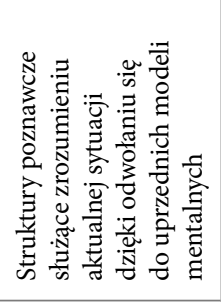 & 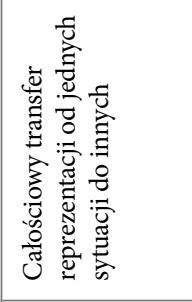 & 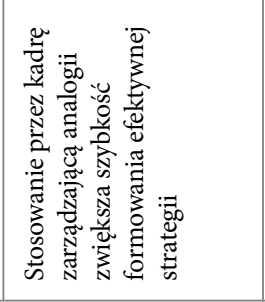 & 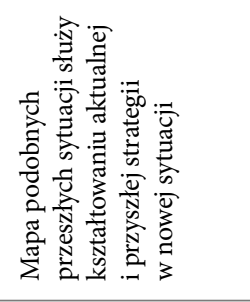 & 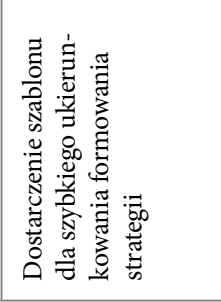 & 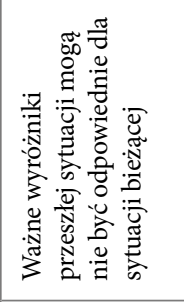 \\
\hline & 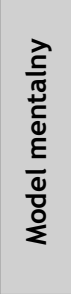 & 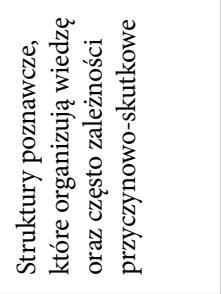 & 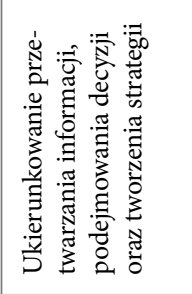 & 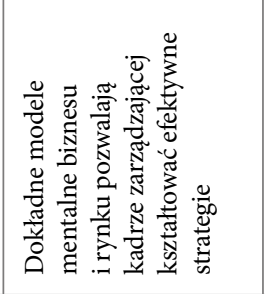 & 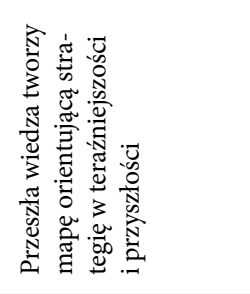 & 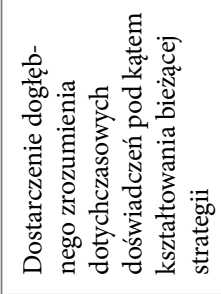 & 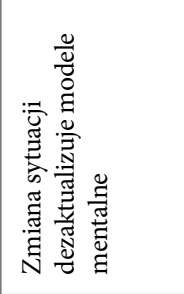 \\
\hline \multirow{4}{*}{ 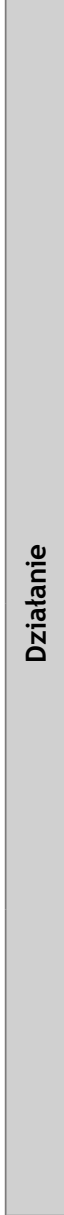 } & 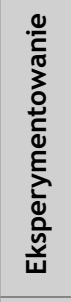 & 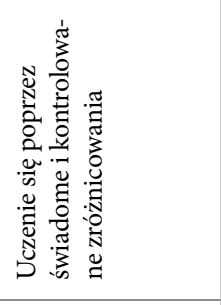 & 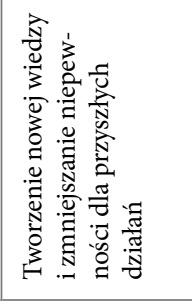 & 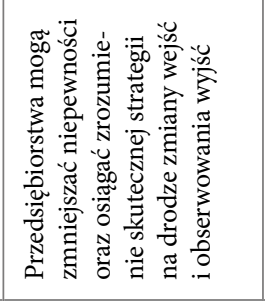 & 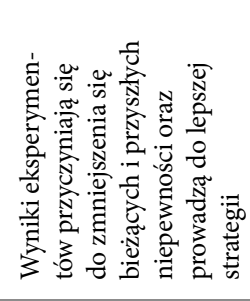 & 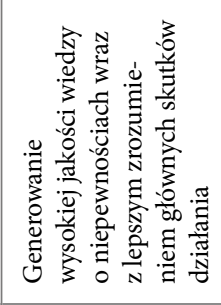 & 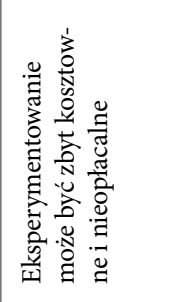 \\
\hline & 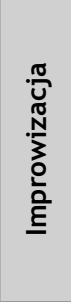 & 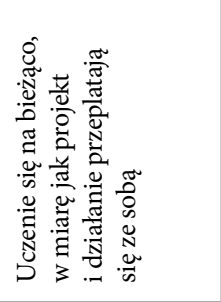 & 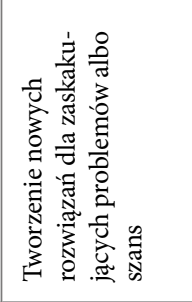 & 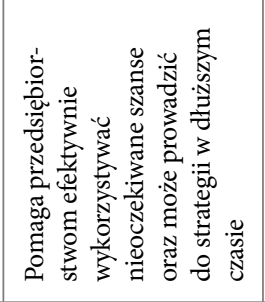 & 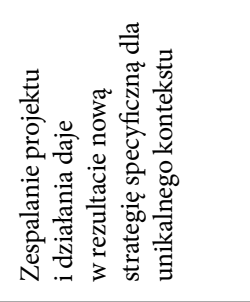 & 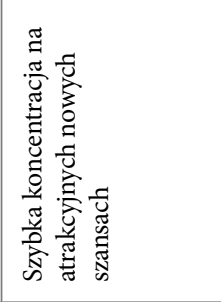 & 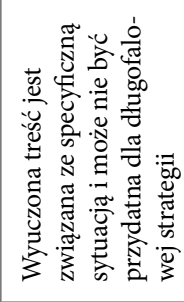 \\
\hline & 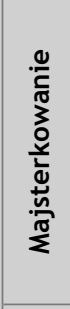 & 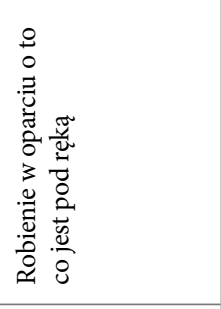 & 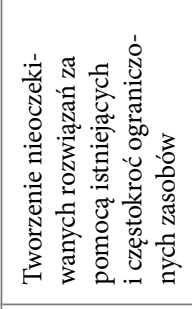 & 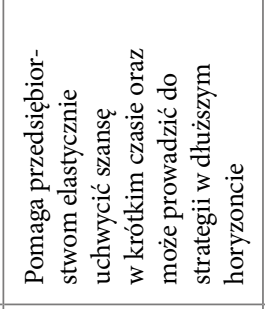 & 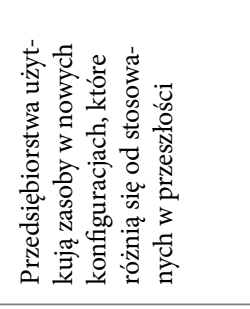 & 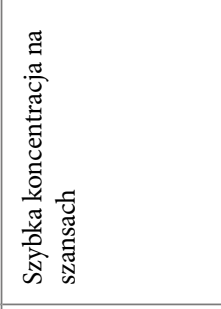 & 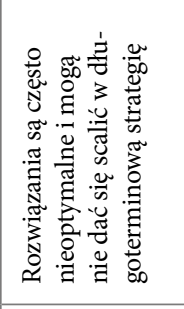 \\
\hline & 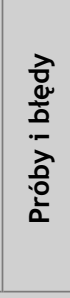 & 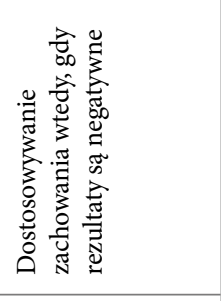 & 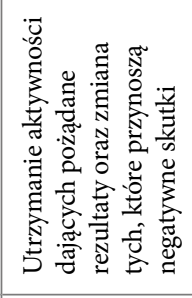 & 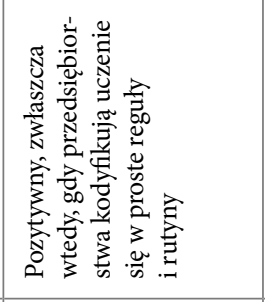 & 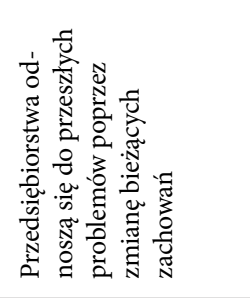 & 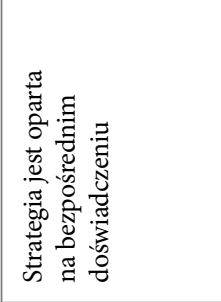 & 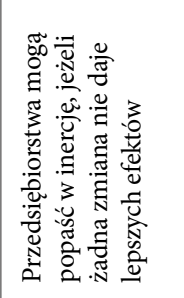 \\
\hline & 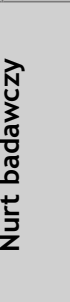 & 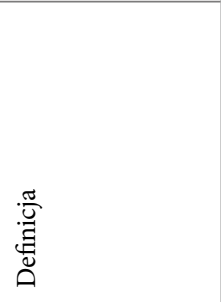 & $\vec{u}$ & 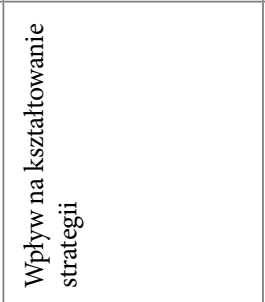 & 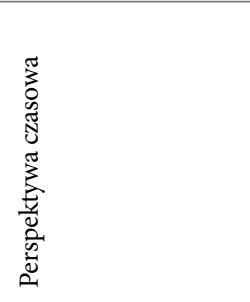 & 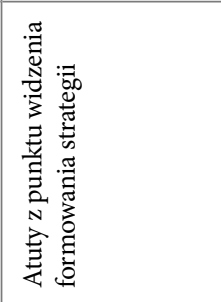 & 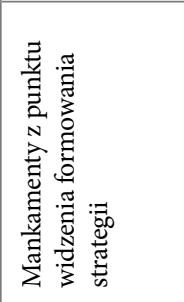 \\
\hline
\end{tabular}


Na drugim krańcu rozważanej sprzeczności strategicznej znajduje się myślenie służące zbudowaniu całościowego zrozumienia $\mathrm{w}$ oparciu o poznanie. W grę wchodzą tutaj modele mentalne, analogie oraz tożsamość. Modele mentalne są pojmowane jako uproszczone struktury poznawcze, dzięki którym stratedzy organizują wiedzę w reprezentację lub mapę ułatwiającą zrozumienie rynków przedsiębiorstw i strategii. Warto $\mathrm{w}$ tym miejscu podkreślić, że kadra zarządzająca posiadająca bardziej całościowe i dokładne modele mentalne, łącznie z logiką przyczynowo-skutkową odnośnie do prowadzonych biznesów, tworzy bardziej efektywne strategie. Nie bez znaczenia jest też wizja rozwojowa, która nierzadko wyłania się z procesu planowania strategicznego. Modelom mentalnym towarzyszy stosowanie analogii. Analogie są strukturami poznawczymi ułatwiającymi rozwiązanie problemu strategicznego dzięki temu, że stratedzy wykorzystują mentalne reprezentacje zapożyczone z doświadczanych wcześniej sytuacji. Zatem analogie sprzyjają kształtowaniu strategii dzięki przyspieszeniu budowania dokładnych i całościowych modeli mentalnych. Całość strategicznego myślenia domyka kwestia tożsamości zarówno osobistej (kim jestem), jak i organizacyjnej (kim jesteśmy). Tożsamość osobista działa $\mathrm{w}$ charakterze filtra informacyjnego oraz instrumentu wbudowywania w strategie preferowanych wartości. Podobnie tożsamość organizacyjna kształtuje sposób, w jaki kadra zarządzająca konceptualizuje strategie.

Oprócz szerzej omówionego wyróżnika organizacji przedsiębiorczych, jakim jest tworzenie wartości w warunkach niepewności, istnieje też wiele innych w ramach różnych podejść $\mathrm{w}$ badaniach przedsiębiorczości. Powiększa to listę dylematów istotnych dla tworzenia strategii przedsiębiorczej. Mogą to być np.: twórczość organizacyjna jako konstrukt wielowymiarowy i wielopoziomowy, tworzenie i przechwytywanie wartości, cechy organizacyjne (wielkość, wiek, forma prawna, forma własności), charakter otoczenia zadaniowego, wynik procesu przedsiębiorczości (rozwój, innowacyjność, wysoka efektywność), zachowania przedsiębiorcze (rozpoznawanie i wykorzystywanie szans), strategiczne ukierunkowanie na rozwój, chęć do podejmowania wyważonego ryzyka, tolerancja nieokreśloności, uczenie się na porażkach, promowanie elastyczności, innowacji oraz odnowy (Bratnicki, Kulikowska, 2009, s. 130; Zbierowski, 2012, s. 20-25).

Dla przykładu strategie poszukiwania szans i przewagi konkurencyjnej potrzebują organizacyjnej twórczości jako zdolności dynamicznej w sytuacji, gdy mają wspierać efektywność organizacji. Twórczość organizacyjna jawi się jako dynamiczna zdolność organizacji, za pomocą której tworzone są nowe i użyteczne idee, a organizacja generuje nowe kompetencje dla lepszego rozwoju wraz z otoczeniem. Nowe i użyteczne idee stają się podstawą ustawicznej dialektycznej dynamiki. Zrozumienie tej dynamiki jest bardzo ważne dla menedżerów i przedsiębiorców kreujących twórcze organizacje.
Kolejny ważny dylemat związany z generowaniem strategii to tworzenie i przechwytywanie wartości w organizacjach. Zagadnienie uzyskiwania różnej efektywności i tworzenia wartości przez organizacje literatura zarządzania strategicznego rozpatrywała do tej pory $z$ różnych perspektyw: względem pozycji firmy w sektorze, przez podejście zasobowe, przez zorientowanie na sieć i dynamikę dostosowywania się organizacji do zmieniającego się otoczenia. Tworzenie wartości przez przedsiębiorstwo opisywane jest najczęściej z punktu widzenia podejścia zasobowego, gdzie kładzie się nacisk na istotną w tym procesie rolę zdolności dynamicznych, rozwijanych bądź przejmowanych, w podwyższaniu efektywności, a także analizuje się konkretne uwarunkowania sektorowe i organizacyjne, gdzie zdolności organizacyjne przekładają się na tworzenie wartości. Dodając do tego pojęcie przechwytywanej wartości, sugeruje się ujęcie tworzenia wartości jako różnicy między skłonnością do zapłaty a wartością użytkową lub wymienną. Zmienną różnicującą wielkość przechwyconej wartości jest poziom tych dwóch rodzajów wartości. Zwiększenie wartości użytkowej wpływa na tworzenie wartości przez organizację, a zwiększenie wartości wymiennej decyduje o możliwości większego przechwytywania wartości.

Zagadnienie tworzenia wartości często łączy się z innowacyjnością, bo celem innowacji jest właśnie tworzenie wartości. Trzeba mieć jednak na uwadze, że nawet najbardziej efektywnie wytworzona wartość nie zwiększy zysków, jeśli innowatorzy (osoby lub przedsiębiorstwa) nie będą w stanie przechwycić znaczącej jej części. Przedsiębiorstwa powinny więc nastawić się nie tylko na tworzenie, ale też na przechwytywanie utworzonej wartości celem uzyskiwania przewagi konkurencyjnej.

Aktualnym zadaniem zarządzania strategicznego jest poszukiwanie źródeł tworzenia wartości. Doszukuje się ich w dynamicznych zdolnościach, unikatowym modelu biznesu, innowacjach, potencjale strategicznym organizacji czy przedsiębiorczości organizacyjnej. Pierwotnym względem nich jednak źródłem tworzenia wartości jest twórczość organizacyjna jako punkt wyjścia do pozostałych procesów, mechanizmów i wyników. Twórczość organizacyjną można zdefiniować jako generowanie idei nowych i potencjalnie użytecznych dla integrowania, budowania i rekonfigurowania strategicznego potencjału przedsiębiorstwa (zasobów i zdolności substancjalnych) w celu osiągnięcia efektywności organizacyjnej przedsiębiorstwa (Bratnicka-Myśliwiec, 2017, s. 42). Dopiero strategiczne umocowanie twórczości organizacyjnej przełoży się na skuteczne tworzenie, zatrzymywanie i przechwytywanie wartości.

\section{Podsumowanie}

$\mathbf{P}$ rzyjęty w artykule cel został zrealizowany przez przedstawienie obrazu współczesnego myślenia o zarządzaniu z jego podstawowymi nurtami oraz wskazanie specyfiki organizacji przedsiębiorczych, aby następnie 
przejść do formułowania strategii przedsiębiorczej na bazie oryginalnie opracowanej koncepcji. Zgodnie $\mathrm{z}$ logiką dialektyczną tworzenia strategii przedsiębiorstwa, chodzi o zorientowanie tego procesu na godzenie potencjalnych sprzeczności, jakie mogą wynikać z decyzji i działań w opisanych aspektach tworzenia strategii.

W opracowaniu przedstawiono szereg implikacji dla teorii i praktyki. W ramach tych pierwszych m.in.: zaprezentowano uwspółcześnioną logikę myślenia o aktualnych problemach nowoczesnego zarządzania, dokonano porównania między spojrzeniem obecnie dominującym a spojrzeniem pożądanym na zarządzanie organizacją oraz przywołano i omówiono koncepcyjną strukturę nośną dla formowania strategii w przedsiębiorczych organizacjach. Przedstawione propozycje teoretyczne pozwalają na radzenie sobie z wielowymiarową rzeczywistością organizacyjną dzięki równoczesnemu uwzględnianiu rozmaitych presji, imperatywów i wymogów. Świadome tworzenie przedsiębiorczej strategii ma swój początek w dialektyce strategicznego działania i myślenia. Proces ten przypomina przebudowywanie statku w czasie pływania po nieznanych wodach konkurencyjności.

$\mathrm{Z}$ artykułu wynikają też implikacje praktyczne. Paradoks swobody manewru strategicznego ożywiającego przedsiębiorczość nie jest wyłącznie ornamentem literackim. Jeżeli organizacja ma być autentycznie efektywna, to należy zmienić ocenę nie tylko dotychczasowych praktyk menedżerskich, ale również podstawowych założeń i wartości charakterystycznych dla kultury organizacyjnej. Można tu mieć na myśli te założenia i wartości kulturowe, które wyodrębniają uczestników organizacji jako społeczność i odgrywają kluczową rolę w niezdolności do osiągnięcia wysokiej efektywności organizacyjnej na liczącą się skalę (np. poczucie moralnej wyższości i wynikająca zeń arogancja wobec standardów współczesnego zarządzania), niechęć do uczenia się od innych, preferowane siłowe rozwiązywanie każdego problemu, nacisk na wymierne efekty i niedocenianie efektywności społecznej, krótka perspektywa czasu, preferowanie biurokracji, brak zaufania do innych, prawie całkowite zaprzeczenie złu jako części każdego człowieka (ignorowanie lub przecenianie roli zła), obojętna postawa wobec wykształcenia, mechanistyczne podejście do organizowania, pierwszoplanowa rola technologii.

Patrząc przez pryzmat działalności menedżerskiej, należy podkreślić, że nie ma rozwiązań problemów strategicznych, które są proste i trwałe, a jednocześnie efektywne. Dlatego też niezbędne jest myślenie dialektyczne, unikające jednostronnego spojrzenia. Zarazem trzeba przestrzec przed koncentracją uwagi jedynie na myśleniu bądź też na działaniu strategicznym. I tak, skupienie się na myśleniu (planowaniu strategicznym) prowadzi do nieuzasadnionej dalekowzroczności, która powoduje uwikłanie w jedną wizję przyszłości. Podobnie postawienie na działanie (strategię wyłaniającą się) daje w efekcie krótkowzroczność powodującą reaktywny sposób działania demobilizujący strategicznie.
Naturalnie przedstawioną koncepcję przedsiębiorczej strategii jako swoistą propozycję odpowiedzi na zmianę paradygmatu zarządzania organizacją należy poddać empirycznemu sprawdzeniu. Przede wszystkim wyzwaniem metodologicznym na tym szlaku jest pomiar efektywności strategii przedsiębiorczej. W tym względzie warto do oszacowania efektywności procesu strategii podejść czterotorowo. Po pierwsze, cenne jest zastosowanie jakościowych ocen, dokonywanych przez kadrę zarządzającą odnośnie do postępów oraz efektywności procesu kreowania strategii. Równie wartościowe jest skorzystanie $\mathrm{z}$ oceny szybkości tego procesu, począwszy od wyłaniania się potrzeby nowej strategii. Po trzecie, przydatne jest zidentyfikowanie skutków tworzenia strategii z opóźnieniem czasowym (na przykład rocznym) w odniesieniu do zakończenia tego procesu. W końcu należy wziąć pod uwagę decyzje podejmowane przez zarządzających dotyczące przedsięwzięć wspierających nową strategię. Ogólnie mówiąc, dążąc do dokładności pomiaru, trudno jest przecenić podejście triangulacyjne obejmujące wskaźniki zarówno ilościowe, jak i jakościowe, pochodzące $\mathrm{z}$ różnych poziomów analizy.

Prowadzone do tej pory rozważania nie zamykają tematu, a wręcz przeciwnie tworzą podstawę do zarysowania kolejnych luk badawczych i określenia dalszych kierunków badań. Do interesujących w tym względzie wątków można zaliczyć m.in.: procesy wyłaniania się struktur poznawczych zwłaszcza w burzliwym otoczeniu; opis równoczesnego myślenia i działania jako rdzenia dialektyki formowania strategii; zagadnienie efektywnych konfiguracji obejmujących próby i błędy, majsterkowanie, improwizację, eksperymentowanie, model mentalny, analogię i tożsamość. W tym ostatnim przypadku wyjaśnienie tego typu wzorców tworzenia strategii oraz ich związków z efektywnością organizacyjną przedsiębiorstwa wymaga zastosowania jakościowej analizy porównawczej. Utrzymując się w tym nurcie metodologicznym, należy też wskazać na użyteczność kombinowania indukcyjnej analizy przypadków z badaniami empirycznymi opartymi na znacznie większych populacjach badawczych. Oprócz tego warto, koncentrując uwagę na poddających się empirycznemu śledzeniu mechanizmach społecznych, uwypuklić w przyszłych badaniach, że przedsiębiorczość organizacyjna ma charakter transformacyjny w sensie zarówno wytwarzania efektów organizacyjnych, jak i przekształcania tożsamości oraz celów. Poczesne miejsce zajmuje tutaj choćby wywieranie wpływu, stanowiące istotę politykowania organizacyjnego, generowanie twórczych idei czy też przywództwo strategiczne.

\footnotetext{
prof. dr hab. Mariusz Bratnicki

Akademia WSB

Wydział Nauk Stosowanych

ORCID: 0000-0002-6566-6108

e-mail: mbratnicki@wsb.edu.pl
} 


\section{mgr Paweł Brzeziński \\ Akademia WSB \\ Wydział Nauk Stosowanych \\ ORCID: 0000-0003-4923-6607 \\ e-mail: pbrzezinski@wsb.edu.pl}

\section{Bibliografia}

[1] Agarwal R., Dushnitsky G., Lumpkin G.T., Wright M., Zott C. (2017), Strategic Entrepreneurship Journal at 10: Retrospect and Prospect, „Strategic Entrepreneurship Journal”, Vol. 11, No. 3, pp. 197-199.

[2] Alvarez S.A., Barney J.B., Mcbride R., Wuebker R. (2017), On Opportunities: Philosophical and Empirical Implication, „Academy of Management Review", Vol. 42, No. 4, pp. 726-730.

[3] Benner M.J., Tushman M.L. (2015), Reflections on the 2013 Decade Award - „Exploitation, Exploration, and Process Management: The Productivity Dilemma Revisited" Ten Years Later, „Academy of Management Review”, Vol. 40, No. 4, pp. 497-514.

[4] Birkinshaw J. (2010), Reinventing Management. Smarter Choices for Getting Work Done, Wiley, Chichester.

[5] Bratnicka-Myśliwiec K. (2016), Paradoks rentowności i konkurencyjności w zarządzaniu strategicznym rozwojem przedsiębiorstwa, „Organizacja i Kierowanie”, Nr 4, s. 57-70.

[6] Bratnicka-Myśliwiec K. (2017), Twórczość w przedsiębiorstwie. Perspektywa obustronności organizacyjnej, Wydawnictwo Uniwersytetu Ekonomicznego w Katowicach, Katowice.

[7] Bratnicki M. (2000), Podstawy wspótczesnego myślenia o zarządzaniu, Wyższa Szkoła Biznesu w Dąbrowie Górniczej, Dąbrowa Górnicza.

[8] Bratnicki M., Kulikowska M. (2009), Kształtowanie przedsiębiorczego rozwoju w małej i średniej firmie, [w:] J. Skalik (red.), Zmiana warunkiem sukcesu. Rozwój i zmiany w malych $i$ średnich przedsiębiorstwach, Wyd. Uniwersytetu Ekonomicznego we Wrocławiu, Wrocław, s. 127-132.

[9] Bratnicki M. (2010), Organizacyjne uczenie się i odnowa strategiczna: Zarys teorii przedsiębiorczego rozwoju organizacji, Prace Naukowe Uniwersytetu Ekonomicznego we Wrocławiu, Nr 128, s. 507-513.

[10] Bratnicki M. (2011), Nadawanie sensu, improwizacja i przedsiębiorczy rozwój organizacji: budowanie domeny badań, Zeszyty Naukowe Uniwersytetu Ekonomicznego w Poznaniu, Nr 189, s. 16-24.

[11] Bratnicki M. (2014), Identyfikacja nowej perspektywy na zarzadzanie organizacjami - spojrzenie $z$ punktu widzenia twórczości organizacyjnej, Raport z badań wykonany w ramach projektu „Metodologia komputerowego wspomagania twórczości", Katowice.

[12] Bratnicki M., Kulikowska-Pawlak M., Dyrbuś-Graca K. (2014), Zdrowie organizacji jako koncepcja doskonałości, „Management Forum Prace Naukowe Uniwersytetu Ekonomicznego we Wrocławiu", Nr 357, s. 9-17.

[13] Cowan D.A., Darsoe L. (2008), Wisdom: A Backdrop for Organizational Studies, [in:] D. Barry, H. Hansen (eds.), The SAGE Handbook of New Approaches in Management and Organization, Sage, Thousand Oaks, pp. 332-343.
[14] Dyduch W. (2013), Twórcza strategia organizacji, Wydawnictwo Uniwersytetu Ekonomicznego w Katowicach, Katowice.

[15] Furr N.R., Nickerson J., Wuebker R. (2017), A Theory of Entrepreneuring, Working Paper, INSEAD, Fontainebleau.

[16] Garg S., Eisenhardt K. (2017), Unpacking the CEO-board Relationship in Entrepreneurial Firms, „Academy of Management Journal", Vol. 60, No. 5, pp. 1828-1858.

[17] Johns G. (2017), Reflections on the 2016 Decade Award: Incorporating Context in Organizational Research, „Academy of Management Review", Vol. 42, No. 4, pp. 577-585.

[18] Judge T.A., Kammeyer-Mueller J.D. (2011), Happiness as a Societal Value, "Academy of Management Perspectives", Vol. 25, No. 1, pp. 30-41.

[19] Lerner J. (2012), The Architecture of Innovation. The Economics of Creative Organizations, Oxford University Press, Oxford.

[20] Ott T.E., Eisenhardt K.M., Bingham C.B. (2017), Strategy Formation in Entrepreneurial Settings: Past Insights and Future Directions, „Strategic Entrepreneurship Journal”, Vol. 11, No. 3, pp. 306-325.

[21] Owens B.P., Johnson M.D., Mitchell T.R. (2013), Expressed Humility in Organizations: Implications for Performance, Teams, and Leadership, „Organization Science”, Vol. 24, No. 5, pp. 1517-1538.

[22] Peck M.S. (2003), The Road Less Traveled: A New Psychology of Love, Traditional Values and Spiritual Growth, Touchstone, New York.

[23] Pentland A. (2014), Social Physics. How Social Networks Can Make Us Smarter, Penguin Books, New York.

[24] Ramoglou S., Tsang E.W.K. (2017), In Defense of Common Sense in Entrepreneurship Theory: Beyond Philosophical Extremities and Linguistic Abuses, „Academy of Management Review", Vol. 42, No. 4, pp. 736-744.

[25] Stanford N. (2013), Organizational Health: An Integrated Approach to Building Optimum Performance, Kogan Page, London/Philapelphia/New Delhi.

[26] Zbierowski P. (2012), Orientacja pozytywna organizacji wysokiej efektywności, Wolters Kluwer Polska, Warszawa.

\section{Harnessing Thinking and Doing in Entrepreneurial Strategy}

\section{Summary}

Research suggests that organisations increasingly face the prospect of high-velocity entrepreneurshipscape, yet relatively little studies have explored strategy creation in entrepreneurial settings. The conceptualisation presented here depicts entrepreneurial strategy as a process that reflects a strategic contradiction between planning and doing. This comprehensive, complex and dynamic model illustrates how contemporary organisations might adapt to limit its inertia-related consequences.

\section{Keywords}

contemporary management, entrepreneurial strategy, planning versus doing 